\title{
Quality of Education and Economic Integration in Central America
}

\author{
Luis Rene Caceres ${ }^{1}$ \\ ${ }^{1}$ Independent Researcher, El Salvador; In Memory of Carlos Ochoa Morales, My Friend. \\ Correspondence: Luis Rene Caceres, 5456 Paseo General Escalón, San Salvador, El Salvador. E-mail: \\ luisrenecaceres@gmail.com
}

Received: July 2, 2021

Accepted: August 26, 2021

Online Published: August 30, 2021

doi:10.5539/ijef.v13n9p154

URL: https://doi.org/10.5539/ijef.v13n9p154

\begin{abstract}
This paper uses the literature that has shown that the main determinant of the economic growth of Latin American countries is the quality of education, measured as the scores obtained in national or international standardized tests. Based on that evidence, it postulated that in the Central American economic integration scheme, if a given country's increases it's education quality, it's rates of investment and economic growth would increase. The increased economic dynamism in this country would lead to increasing its imports from other member countries and in consequence, would experience more rapid rates of economic growth.

Moreover, it is shown that the GDP increases resulting from increases in education quality would be larger when they take place on a Central American basis, that is, when each country increases its education quality simultaneously, than when they occur on an individual basis, a result that can viewed as a regional concertation externality.

The paper concludes arguing that it is important that Central American countries increase their education quality to acquire a capacity to grow endogenously.
\end{abstract}

Keywords: economic integration, regional externalities, economic interdependence, economic growth

\section{JEL: F15, F16, F63, I25.}

\section{Introduction}

The quality of education is a topic that continues to receive attention in Economics. The interest stems from the evidence presented by various authors that quality of education is an important determinant of economic growth. In recent years it's observed that studies on the influence of human capital on economic development emphasize the role of the knowledge acquired by students in school, and not simply the number of years that students stay in the educational system. This knowledge, which represents the quality of education, is usually measured by the scores obtained by students in national or international tests of reading or mathematics.

In view of its role in increasing economic growth, it is valid to postulate that if one or several member countries of an economic integration scheme improve their quality of education, they will experience increases in their economic growth rates, and therefore they will "share" their economic dynamism with the other member countries, through increases in intra-regional trade flows, thus giving rise to a regional network of economic growth impulses.

The objective of this paper is the quantification of such a network of growth impulses at the Central American level. The next section presents a brief overview of the relationships between quality of education and economic growth. This is followed by the development of a theoretical model derived from Metzler (1950) model, which is estimated to compute the multiplier matrix, and to quantify the repercussions on the Central American countries derived from increasing the quality of education by one, or several, member countries. The virtuous circles resulting from increases in the quality of education are analyzed as well. The work ends with a series of conclusions.

\section{Review of Selected Literature on the Quality of Education and Economic Development}

This section presents a brief review of the literature on the role of educational quality in economic development.

Jamison, Jamison, and Hanushek (2007) pointed out the way in which the quality of education leads to increasing the economic growth rate of a given country, which lies in enhancing its capacity to increase its rate of technological progress and innovation. In the same sense, Hanushek and Woessmann (2009a) have argued that 
the quality of education allows the diffusion and acquisition of technologies, thus increasing the capacity for innovation, and therefore increasing labor productivity.

It should be noted that there is microeconomic evidence of the role of the quality of education in increasing the income of individuals. Hanushek (2005) showed that students' labor market performance after graduating from high school was such that those with higher test scores in their final year of high school, subsequently had higher monthly earnings.

There is also evidence that public expenditure directed to increasing quality of education pays for itself. Hanushek and Woessmann (2007) showed that the increase in the quality of education from 450 to 500 points in international tests in the last year of secondary school, leads the respective country in a horizon of 60 years, to have a GDP 25 percent higher than in the case in which it had not invested in increasing it.

Regarding the Latin American countries, reference is made to the study by Hanushek and Woessmann (2009b), who estimated various equations to explain the per capita economic growth of these countries using various independent variables, including the scores resulting from the standardized tests carried out in Latin American countries by the Second Regional Evaluation of the Quality of Education in 2005 (SERSE, 2008). The results indicated that the average country scores were the most important determinants of economic growth in the region.

Several authors have tried to identify the variables that determine the quality of education in a country. The study by Jackson, Johnson and Persico (2015) on the impacts of increasing spending per student in USA schools, reported that the 10 percent increase in spending per student in each year of the twelve years of public education, led to an increase in the level of schooling by 0.43 additional years, an increase of 9.5 percent in wages, and a reduction of the poverty rate of adults by 6.8 percent.

Tsounta and Osueke (2014) presented evidence that the scores of the Latin American countries on the PISA tests increase with public spending on education as a percentage of GDP.

Regarding the relationship between spending per student and their performance, Hanushek and Kimbo (2000) reported that the shortage of teaching materials had a negative impact on the quality of education.

The positive impact of teachers' salaries has been reported by Lee and Barro (2001) and by Dalton and Marcenaro-Gutierrez (2010). Hanushek, Piopiunik, and Wiederhold (2014) reported that, in a sample of OECD countries, the quality of teachers and the amounts of their salaries had significant impacts on student scores in the PISA. On the other hand, based on the analysis of the results of grades 7 and 8 of the TIMSS, Woessmann (2003) and Woessmann and West (2006) reported that the negative impact of the number of students per teacher decreased as the level of teacher proficiency and wages increased.

Of particular importance is the evidence that eighth grade students' standardized test scores increased proportionally with the time they spent at the preschool level (Schuetz, Ursprung, \& Woessmann, 2008).

The study by Arias, Yamada, and Tejerina (2002) on education and wages in Brazil, used the ratio of students to teacher as an indicator of the quality of education, and reported that as this index increased the rate of return of education fell, so that a reduction of 10 students in this ratio would lead to an increase in the average rate of return of 0.9 points. A similar result was reported by Card and Krueger (1992) for the US. With respect to the number of students per teacher, Barro and Lee (2001) reported that its reduction had a positive impact on quality of education, a result that has also been pointed out by McEwan (2014).

\section{Data}

The main source of data is the World Bank's World Development Indicators.

The means values and standard deviations of the variables are presented on table 1 .

Table 1. Means and standard deviations of variables.

\begin{tabular}{lcc}
\hline Variable & Mean & Standard deviation \\
\hline Sixth grade Reading & 700.00 & 41.22 \\
Third grade math & 700.00 & 47.38 \\
Sixth grade science & 699.00 & 38.82 \\
Economic growth & 4.78 & 1.88 \\
Export per capita & 1978.64 & 1519.47 \\
Private investment & 17.75 & 3.73 \\
Public spending education & 4.20 & 1.23 \\
Students per teacher ratio & 22.28 & 5.59 \\
\hline
\end{tabular}




\section{Quality of Education and Macroeconomics in Latin American Countries}

As an indicator of the quality of education in the Latin American countries, this paper uses the scores on the Third Regional Comparative and Explanatory Study, prepared by the Latin American Laboratory for Assessment of Quality of Education, (UNESCO-TERCE, 2016), which included reading, mathematics, and science tests, conducted in 2013, in 15 countries of the region, and with a coverage of 67,000 students. The average country scores are presented on table 2 .

Table 2. Average country scores

\begin{tabular}{|c|c|c|c|c|c|c|c|}
\hline & \multicolumn{2}{|c|}{ Third Grade } & \multicolumn{2}{|c|}{ Sixth grade } & \multirow[b]{2}{*}{ Science } & \multirow{2}{*}{$\begin{array}{c}\text { EducationG Expenditure } \\
2005-2014\end{array}$} & \multirow{2}{*}{$\begin{array}{c}\text { Puplils/Teacher } \\
\text { 2005-20142 }\end{array}$} \\
\hline & Reading & Mathematics & Reading & Mathematics & & & \\
\hline ARGENTINA & 703 & 717 & 707 & 722 & 700 & 5.1 & 16 \\
\hline BRASIL & 712 & 727 & 721 & 709 & 700 & 5.8 & 21 \\
\hline CHILE & 802 & 787 & 776 & 793 & 768 & 4.6 & 21 \\
\hline COLOMBIA & 714 & 694 & 726 & 705 & 733 & 4.9 & 25 \\
\hline COSTARICA & 754 & 750 & 755 & 730 & 756 & 6.9 & 16 \\
\hline ECUADOR & 698 & 703 & 683 & 702 & 711 & 4.4 & 19 \\
\hline GUATEMALA & 678 & 672 & 678 & 672 & 684 & 2.8 & 26 \\
\hline MEXICO & 718 & 741 & 735 & 768 & 732 & 5.1 & 28 \\
\hline NICARAGUA & 654 & 653 & 662 & 643 & 668 & 4.4 & 30 \\
\hline PANAMA & 670 & 664 & 671 & 644 & 675 & 3.3 & 25 \\
\hline PARAGUAY & 653 & 652 & 652 & 641 & 646 & 5 & 22 \\
\hline PERU & 719 & 716 & 703 & 721 & 701 & 3.3 & 18 \\
\hline URUGUAY & 728 & 742 & 736 & 765 & 725 & 4.4 & 14 \\
\hline HONDURAS & 681 & 680 & 662 & 661 & 668 & & 34 \\
\hline R.DOMINICANA & 614 & 602 & 633 & 622 & 632 & 3.8 & 24 \\
\hline ELSALVADOR $^{1}$ & 673 & 678 & 673 & 677 & & 3.2 & 26 \\
\hline
\end{tabular}

Note. ${ }^{1}$ El Salvador did not participate in the TERCE evaluation, the scores shown on table 2 are imputed by means of statistical analysis.

Regarding the determinants of the quality of education, the TERCE scores allow corroborating the findings of several studies that the scores are positively related to public spending on education as a percentage of GDP, as shown in Figure 1.

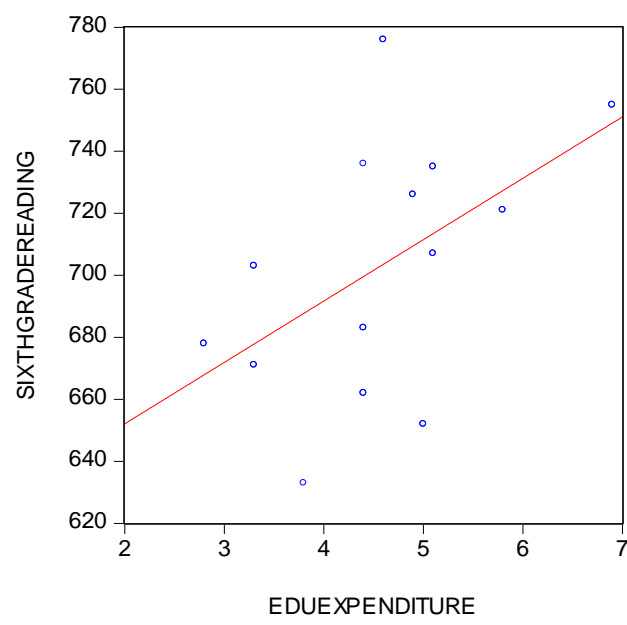

Figure 1. Public spending on education as a percentage of GDP, (eduexpenditure), and reading scores in sixth grade (sixthgradereading)

Likewise, in accordance with the literature on this subject, Figure 2 shows that there is a negative relationship between the number of students per teacher, (studentsteacher), and the mathematics scores in third grade (thirdgrademath). 


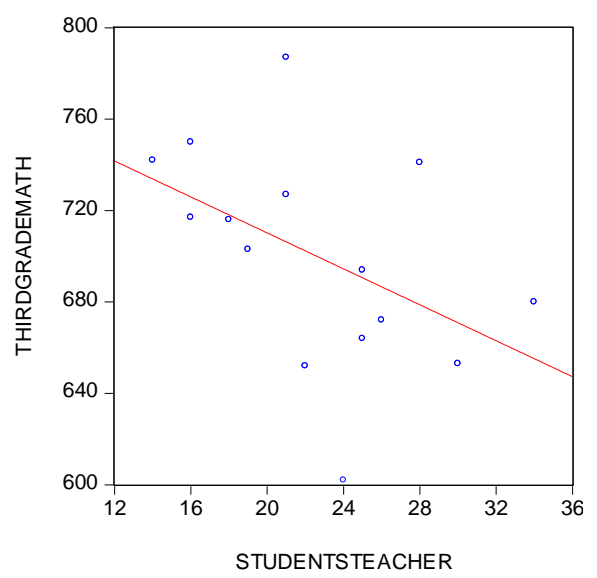

Figure 2. Number of students per teacher and math scores in third grade

The quality of education has an impact on macroeconomic variables. Figure 3 shows the relationship between sixth grade math scores and the 2013 national savings rate, (national savings), while Figure 4 shows a close association between third grade reading scores, (thirdgradescoring), and the rate of private investment (privateinvestment).

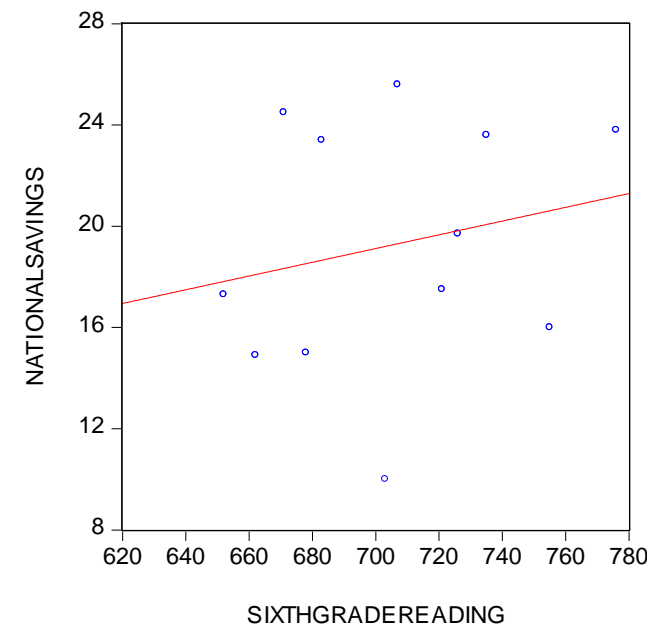

Figure 3. Sixth grade reading scores and national savings rate

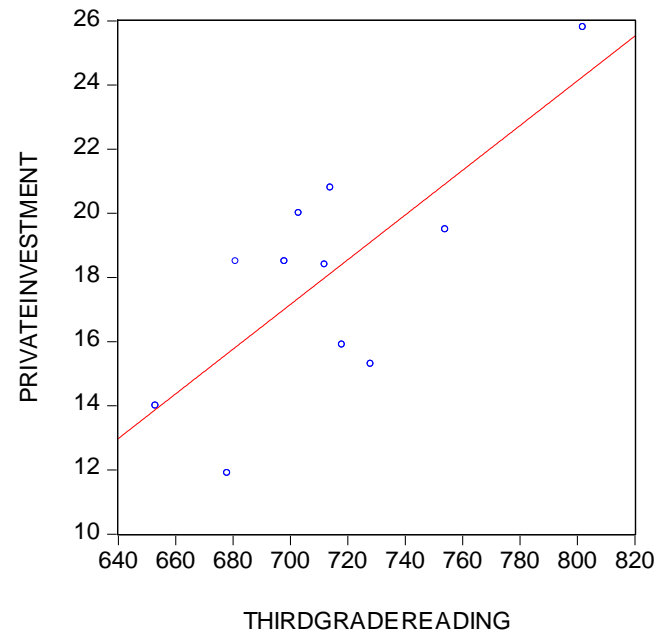

Figure 4. Third grade reading scores and private investment rate 
In view of the role of public spending on education in increasing the quality of education (Figure 1), a positive relationship is also observed between spending on education as a percentage of GDP and the 2013 private investment rate, as can see in Figure 5.

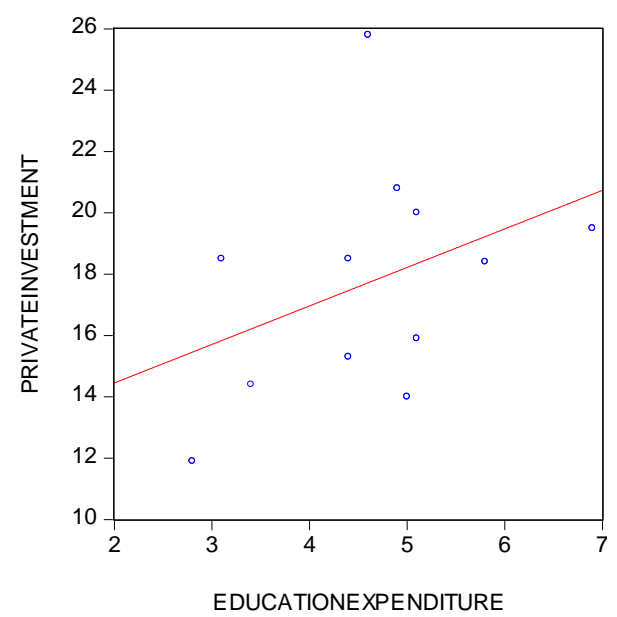

Figure 5. Public spending on education as a percentage of GDP and private investment rate.

Importance for the objectives of this paper lies in quantifying the impact of quality of education on private investment. Equations that express the private investment rate in terms of variables that represent the quality of education are shown on table 3 , where the qualitative variable Cuali, takes the value of one when the variables correspond to Chile, and zero otherwise.

Table 3 shows that reading and science scores explain about 50 percent of the variance of private investment, while public spending on education explains 72 percent.

Table 3. Quality of education, public spending on education and private investment rate ${ }^{1}$

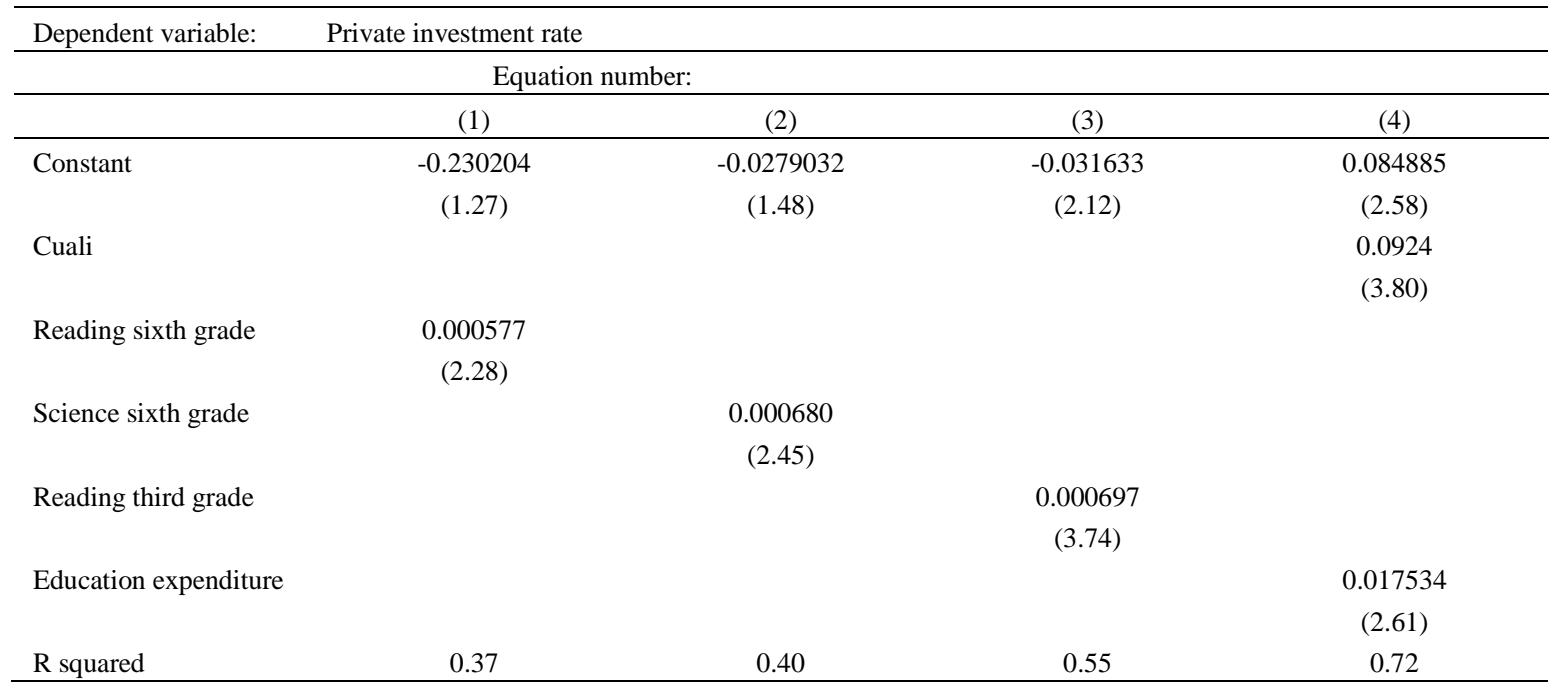

Note. ${ }^{1}$ In this and all tables the " $\mathrm{t}$ " statistics are shown underneath the corresponding coefficients.

\section{The Proposed Model}

The proposed model rests on the evidence of the role of quality of education in affecting certain national economic and social variables. This makes it possible to postulate that in an economic integration scheme characterized by macroeconomic interdependence relationships, the macroeconomic impacts resulting from changes in the quality of education in a member country will be transmitted to other countries through intra-regional trade channels, thus affecting the macroeconomic variables of all member countries. 
The model developed is based on the well-known work of Metzler (1950), and in that sense it is linear and activated by demand, and assumes that there are no limitations on the supply side.

The gross domestic product of country $\mathrm{i}, \mathrm{Yi}$, is given by:

$$
Y i=C i+G i+I i+I g i+E o i-M o i+\sum(E i j-M i j)
$$

Where:

$\mathrm{Ci}=$ private consumption

$\mathrm{Gi}=$ Public consumption

Ipi $=$ Private investment

Igi $=$ Public investment

Eoi $=$ extra-regional exports

Moi $=$ extra-regional imports

Eij $=$ exports from country $i$ to $j$

Mij = imports of $\mathrm{i}$ from $\mathrm{j}$, equal to Eji

And $\sum$ represents the summation sign.

Private consumption and investment, $\mathrm{Ci}$ and Ipri, and public consumption and investment, Gi and Igi, as well as imports from outside the region, Moi, are assumed assumed to be determined by GDP:

$$
\begin{aligned}
C i & =a i Y i \\
G i & =b i Y i \\
I p i & =c i Y i \\
I g i & =d i Y i \\
M o i & =e i Y i
\end{aligned}
$$

Intraregional exports, Eij, and imports, Mij, depend on the GDP of the importing country:

$$
\begin{aligned}
E i j & =x i j Y j \\
M i j & =m i j Y i
\end{aligned}
$$

By substituting equations (2) - (8) in equation (1) it is obtained that:

$$
\left(1-f+\sum m i j\right) Y i-\sum x i j Y j=E o i
$$

Where $\mathrm{f}=\mathrm{ai}+\mathrm{bi}+\mathrm{ci}+\mathrm{di}-\mathrm{ei}$

The expression (9) can be represented in matrix terms:

$$
\text { (A) }(Y)+(B)(Y)=(A+B)(Y)=(E o)
$$

Where $(\mathrm{A})$ is a diagonal matrix with elements equal to:

Aii $=1-\mathrm{f}+\sum \mathrm{mij}$, and with elements outside the main diagonal equal to zero.

$\mathrm{B}$ is a matrix with zeros on the main diagonal and with elements outside the main diagonal equal to:

$$
B i j=-x i j
$$

$\mathrm{Y}$ is the vector of GDPs of the countries, Eo is the vector of extra-regional exports, and $(\mathrm{A}+\mathrm{B})$ is the Metzler matrix (T).

The vector of GDP can be obtained from the expression (10):

$$
(Y)=(A+B)^{-1}(E o)=(T)^{-1}(E o)
$$

The quality of education is introduced in the model through the result of equation (3) of table 3 , which expresses the propensity to invest by the private sector, (ci), in terms of third grade reading score, Hi:

$$
c i=h i(H i)
$$

Therefore, the elements of matrix A can now be written as:

$$
A i i=1-a i-b i-d i+e i-h i(H i)+\sum m i j
$$

The matrix A can be written as:

$$
A=C+D
$$


Where $\mathrm{C}$ and $\mathrm{D}$ are diagonal matrices with elements equal to:

$$
\begin{gathered}
C i i=1-a i-b i-d i-e i+\sum m i j \\
D i i=h i(H i)
\end{gathered}
$$

And off-diagonal elements equal to zero.

Equation (10) can be written like this:

$$
(C+D+B)(Y)=(E o)
$$

The effects of the changes in the quality of education in a given country on the GDP's vector are found by deriving the expression (12) with respect to $\mathrm{Hi}$ :

$$
\left(\frac{\partial C}{\partial H i} d H i+\frac{\partial D}{\partial H i} d H i+\frac{\partial B}{\partial H i} d H i\right)(\mathrm{Y})+(\mathrm{C}+\mathrm{D}+\mathrm{B}) \frac{\partial Y}{\partial H i} d H i=\frac{\partial E o}{\partial H i} d H i
$$

Since: $\frac{\partial C}{\partial H i}=\frac{\partial B}{\partial H i}=\frac{\partial E o}{\partial H i}=0$

It is obtained that:

$$
\left(\frac{\partial D}{\partial H i} d H i\right)(\mathrm{Y})+(\mathrm{C}+\mathrm{D}+\mathrm{B})\left(\frac{\partial Y}{\partial H i} d H i\right)=0
$$

solving for $\frac{\partial Y}{\partial H i} d H i$ :

$$
\frac{\partial Y}{\partial H i} d H i=(\mathrm{C}+\mathrm{D}+\mathrm{B})^{-1}\left(-\frac{\partial D}{\partial H i} d H i\right)(\mathrm{Y})
$$

The multiplier matrix is equal to $(\mathrm{T})^{-1}$ and therefore the expression (14) can be written like this:

$$
\frac{\partial Y}{\partial H i} d H i=(\mathrm{T})^{-1}\left(-\frac{\partial D}{\partial H i} d H i\right)(\mathrm{T})^{-1}(\text { Eoi })
$$

The acceleration of economic growth is given by the expression:

$$
\frac{\partial^{2} Y}{\partial t \partial H} d H i=(\mathrm{T})^{-1}\left(-\frac{\partial D}{\partial H i} i\right) d H(\mathrm{~T})^{-1} \frac{\partial E o i}{\partial t}
$$

Equation (16) implies that economic growth results both from the evolution of exogenous variables, that is, extra regional exports, as well as from structural change within the regional economic structure. The structural changes are the results of improvements of the quality of education.

\section{Results}

The parameters of equations (2) - (8) were computed using mean values of the variables for the years 2015 and 2016, taken from the World Bank's World Development Indicators. With this basis, the Metzler matrix (A + B + C) was calculated, which is presented in Table 4, where the letters GUA represent Guatemala, ES, El Salvador, H0, Honduras, NI, Nicaragua, CR, Costa Rica and PA shows Panama.

Table 4. Metzler matrix

\begin{tabular}{lcccccc}
\hline & GUA & ES & HO & N & CR \\
\hline GUA & 0.3100 & -0.0582 & -0.0432 & -0.0436 & -0.0074 \\
ES & -0.0110 & 0.4230 & -0.0361 & -0.0273 & -0.0043 \\
HO & -0.0036 & -0.0142 & 0.6335 & -0.0168 & -0.0046 & -0.0023 \\
N & -0.0015 & -0.0107 & -0.0036 & 0.7253 & -0.0023 & -0.0010 \\
CR & -0.0079 & -0.0115 & -0.0159 & -0.0400 & -0.0006 \\
PA & -0.0085 & -0.0043 & -0.0092 & -0.0021 & -0.000000 & 0.8500 \\
\hline
\end{tabular}

The multiplier matrix obtained by taking the inverse of the Metzler matrix, and is shown in Table 5: 
Table 5. Multiplier matrix.

\begin{tabular}{lcccccc}
\hline & GUA & ES & HO & N & CR & PA \\
\hline GUA & 3.24825189 & 0.462758928 & 0.250904631 & 0.221795649 & 0.058853437 & 0.019975083 \\
ES & 0.087578103 & 2.384193769 & 0.143133391 & 0.0997106 & 0.024822612 & 0.007456107 \\
HO & 0.020865616 & 0.057279624 & 1.583664686 & 0.040501033 & 0.00729106 & 0.002245413 \\
N & 0.008330605 & 0.036660558 & 0.010710967 & 1.381282227 & 0.007436168 & 0.001219391 \\
CR & 0.059794755 & 0.073055777 & 0.06398154 & 0.127945823 & 2.176688048 & 0.026294957 \\
PA & 0.033467439 & 0.017760327 & 0.020716581 & 0.007205521 & 0.011566794 & 1.176865302 \\
\hline
\end{tabular}

The multiplier matrix indicates that, for example, if Honduras' extra-regional exports increased by 100 US dollars, its GDP would increase by 158.36 US dollars, while the GDPs of Guatemala and El Salvador would increase by 25.10 and 14.31 US dollars respectively. Guatemala is the country that receives the largest multipliers from the other countries; in second place in terms of the size of the multipliers received is Costa Rica, followed by El Salvador, while the last place corresponds to Panama, which reflects its relative long distance from the other countries.

\subsection{Impacts of Changes in the Quality of Education}

Three cases of increases in the quality of education in given countries are analyzed below. In the first case, it is assumed that Guatemala's score in reading at third grade increases by 50 percentage points. The expression $\frac{\partial D}{\partial H} d H$ is equal to:

$$
\frac{\partial D}{\partial H} d H=\left[\begin{array}{cccccc}
0.0034 & 0 & 0 & 0 & 0 & 0 \\
0 & 0 & 0 & 0 & 0 & 0 \\
0 & 0 & 0 & 0 & 0 & 0 \\
0 & 0 & 0 & 0 & 0 & 0 \\
0 & 0 & 0 & 0 & 0 & 0 \\
0 & 0 & 0 & 0 & 0 & 0
\end{array}\right]
$$

From the computations indicated by equation (15) changes in GDPs are given by the expression:

$$
\frac{\partial}{\partial H}\left[\begin{array}{c}
\text { YGUA } \\
\text { YES } \\
\text { YHO } \\
\text { YN } \\
\text { YCR } \\
\text { YPA }
\end{array}\right] \quad d H=\left[\begin{array}{l}
731.67 \\
19.73 \\
4.7 \\
1.87 \\
13.47 \\
7.54
\end{array}\right]
$$

This vector indicates that the GDP of Guatemala increases by 731.67 million US dollars, which is equivalent to a growth of 1.10 percent, while El Salvador experiences an increase of 19.73 million, or 0.10 percent.

In the second case, El Salvador's third grade reading score is assumed to increase by 50 points. The expression $\frac{\partial D}{\partial H} d H$ is equal to:

$$
\frac{\partial D}{\partial H} d H=\left[\begin{array}{rrrrrr}
0 & 0 & 0 & 0 & 0 & 0 \\
0 & 0.0034 & 0 & 0 & 0 & 0 \\
0 & 0 & 0 & 0 & 0 & 0 \\
0 & 0 & 0 & 0 & 0 & 0 \\
0 & 0 & 0 & 0 & 0 & 0 \\
0 & 0 & 0 & 0 & 0 & 0
\end{array}\right]
$$

Therefore, the changes of the regional GDP vector are found by equation (15): 
$\frac{\partial}{\partial H}\left[\begin{array}{c}\text { YGUA } \\ \text { YES } \\ \text { YHO } \\ \text { YN } \\ \text { YCR } \\ \text { YPA }\end{array}\right] d H=\left[\begin{array}{l}36.98 \\ 190.5 \\ 4.57 \\ 2.93 \\ 5.84 \\ 1.42\end{array}\right]$

The results indicate that the 50-point increase in the third-grade reading score in El Salvador leads to its GDP increasing by 190.50 million, which is equivalent to a 0.81 percent increase in economic growth, while the GDP of Guatemala increases by 36.98 million, which represents an increase of economic growth of 0.06 percent per year.

To estimate the cost of the 50-point increase in the third grade reading test, the following equation was estimated:

Third grade reading score $=632.96+100.34$ Cualich +14.94 Expenditure on education as percentage of GDP

$\mathrm{R} 2=0.74$

Using this equation, the increase in public spending as a percentage of GDP required for the third-grade reading score to increase by 50 points, is 3.3 percentage points. After 25 years, El Salvador's accumulated growth would be 20 percent of GDP, $(0.81 \times 25)$; given that the El Salvador's tax ratio is 18 percent, the additional collection of tax revenue would be 3.6, (20x0.18), percent. It can see that the increase in spending on education by 3.3 percentage points generates an additional 3.6 per cent tax revenue; therefore, it can be deduced that this investment pays for itself.

An additional calculation was carried out to compute the effects of all countries increasing their scores on the third-grade reading test by 50 points.

In this case the matrix $\frac{\partial D}{\partial H} d H$ is equal to:

$$
\frac{\partial D}{\partial H} d H=\left[\begin{array}{llllll}
0.0034 & 0 & 0 & 0 & 0 & 0 \\
0 & 0.0034 & 0 & 0 & 0 & 0 \\
0 & 0 & 0.0034 & 0 & 0 & 0 \\
0 & 0 & 0 & 0.0034 & 0 & 0 \\
0 & 0 & 0 & 0 & 0.0034 & 0 \\
0 & 0 & 0 & 0 & 0 & 0.0034
\end{array}\right]
$$

The changes in the vector of GDPs are given by:

$$
\frac{\partial}{\partial H}\left[\begin{array}{c}
\text { YGUA } \\
\text { YES } \\
\text { YHO } \\
\text { YN } \\
\text { YCR } \\
\text { YPA }
\end{array}\right] \quad d H=\left[\begin{array}{c}
811.50 \\
231.06 \\
125.97 \\
68.30 \\
456.28 \\
233.07
\end{array}\right]
$$

El Salvador's GDP experiences an increase of 1.0 percent, while Guatemala's GDP increases by 1.22 percent, and Costa Rica's by 0.80 percent. This exercise indicates that concerted action at the Central American level in relation to increasing the quality of education, can be more valuable in achieving higher economic growth rates than if the increases were made exclusively at the national level. This is a case in which regional concerted action yields greater benefits than national actions, insofar as it gives rise to a series of additional impulses of economic growth with regional coverage.

In view of the additional increase in economic growth that El Salvador receives, over a 25-year horizon, the additional accumulated GDP would be 25 percent, which would lead to an additional tax collection of 4.5 percent, which is higher than the 3.3 percent required to increase its score by 50 points. In other words, concerted regional action to increase quality of education "reduces" the costs of the required investments. This result can 
be called the creation of regional externalities of a social nature, which has gone unnoticed in the literature on economic integration.

It should be noted that these increases in the GDP of Guatemala and Costa Rica, of 811 and 456 million respectively, are equivalent to GDP increases resulting from the increases in their own extra-regional exports by 248 and 210 million. These increases in extra-regional exports depend on the international economy, but the increases in education quality depend on national fiscal and education policies. In other words, the improvement of quality of the education constitutes a means to "shield" the national economies from the vicissitudes of the international economy and to acquire the capacity for self-determination in economic matters.

\subsection{Import Substitution Scenarios}

The multiplier matrix was calculated under the scenario in which the average propensity to import from outside the region decreases by 0.10 in each country, and that this decrease in extra-regional imports translates into increases in the average propensity to import intra regionally by 0.02 in each country. In this case, the multiplier matrix shows elements of greater dimension than those corresponding to the original multiplier matrix, as seen on table 6 .

After performing the computations indicated by expression (15), using the matrix shown in table 6, the impact of increasing El Salvador's third grade reading score by 50 points results in increasing the vector of GDPs in greater dimensions than in the case without import substitution, which are translate into the following increases in GDP growth rates in percentage points: Guatemala: 2.30; El Salvador: 2.38; Honduras: 1.48; Nicaragua: 1.56; Costa Rica: 1.40; Panama: 0.7.

Table 6. Multiplier matrix under assumption of import substitution.

\begin{tabular}{lcccccc}
\hline & GUA & ES & HO & N & CR & PA \\
\hline GUA & 5.2885 & 1.5302 & 0.8798 & 0.7758 & 0.6266 & 0.2900 \\
ES & 0.6623 & 3.3903 & 0.4842 & 0.3910 & 0.3436 & 0.1606 \\
HO & 0.3273 & 0.3315 & 1.9740 & 0.1954 & 0.1849 & 0.0886 \\
N & 0.2554 & 0.2564 & 0.1454 & 1.6705 & 0.1539 & 0.0721 \\
CR & 0.5640 & 0.5079 & 0.3433 & 0.4015 & 2.9121 & 0.1707 \\
PA & 0.2609 & 0.2048 & 0.1413 & 0.1119 & 0.1406 & 1.3606 \\
\hline
\end{tabular}

This indicates that the structural change resulting from import substitution constitutes a valuable instrument for energizing economies within the framework of an economic integration scheme. Given the stagnation tendencies shown by the Central American countries after the reforms of the 1990s, import substitution emerges as an economic policy option of singular value.

\subsection{Role of Distance}

Figures 6 and 7 show the multipliers received by Guatemala from the other Central American countries in terms of distance, in kilometers. Figure 6 shows the case of the original multiplier matrix, while Figure 7 represents the multipliers under the assumption that a change in import substitution had occurred (table 6). It is observed that in both cases, as the distance from Guatemala City increases, the multipliers tend to fall, but less than in the case when import substitution has occurred

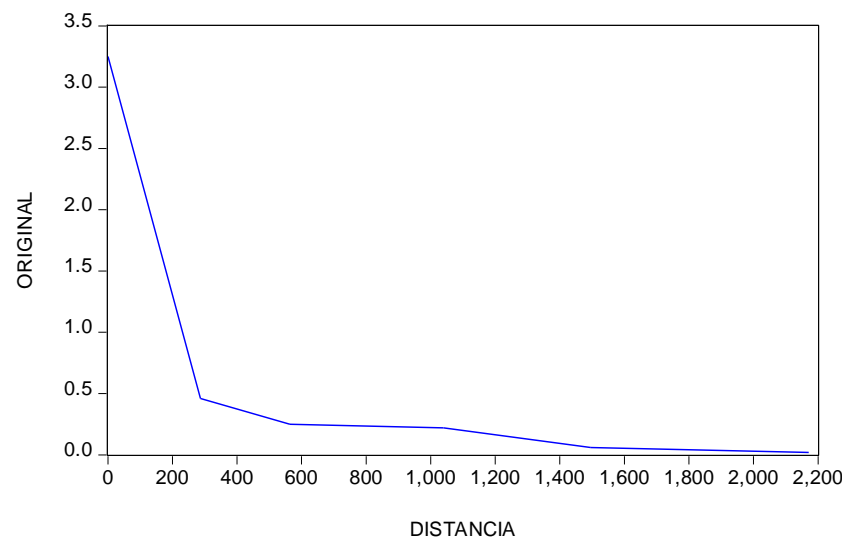

Figure 6. Multipliers received by Guatemala from the other countries 


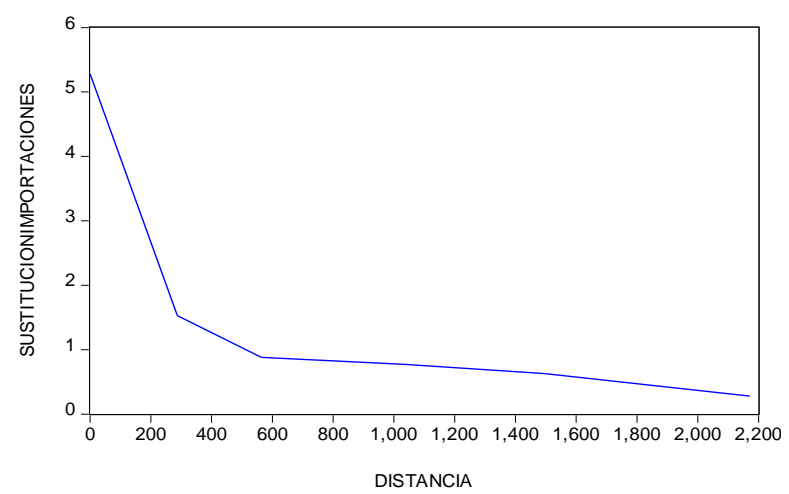

Figure 7. Multipliers received by Guatemala from other countries, under the assumption of import substitution

\subsection{Interdependence in an Integration Scheme}

As defined by Engerman (1968), the interdependence index of an economic system is defined as the increase in GDP in a given country resulting from the increase in its extra regional exports relative to the sum of the increases it experiences when the extra-regional exports of the other member countries increase, that is:

Interdependence index $=\frac{\frac{\partial Y i}{\partial E o i}}{\sum \frac{\partial Y i}{\partial E o j}}$

These indices are shown in table 7 for the original multiplier matrix, and for the multiplier matrix that resulted from the import substitution exercise.

Table 7. Indices of interdependence. Increase in GDP in a country resulting from the increase in its extra-regional exports relative to the sum of the increases it experiences when the extra regional exports of other countries increase

\begin{tabular}{lcc}
\hline Country & Original matrix & Matrix with import substitution \\
\hline Guatemala & 3.2025 & 1.2891 \\
El Salvador & 6.4566 & 1.5301 \\
Honduras & 12.1586 & 1.5963 \\
Nicaragua & 20.7761 & 1.7114 \\
Costa Rica & 2.1853 & 0.7865 \\
Panamá & 12.4823 & 1.4291 \\
\hline
\end{tabular}

A low interdependence index indicates that the corresponding country is more connected to the rest of the member countries and therefore the interdependence is greater. In other words, the low index implies that the country in question "shares" its income more with the other members of the integration scheme, that is, there is less economic polarization. It is observed that in the import substitution scenario, the interdependence indices of all the countries become lower, denoting increases in connectivity in the integration system. The country with the greatest interdependence with the rest of the system, in both cases, is Costa Rica, followed by Guatemala and El Salvador.

In the case of import substitution, the disparities between the interdependence indices decrease substantially, indicating that all countries tend to become interdependent in the same degree. In other words, import substitution can make the integration system more balanced, which has implications for the distribution of the costs and benefits of integration.

The above shows the potential benefits of reestablishing the import substitution model in the Central American countries, which, contrary to what was argued in the 1990s, was not "exhausted", as Rodrik (1998) has shown.

\subsection{Virtuous Circles of Quality of Education}

Figure 8 presents a series of virtuous circles that result from the role of educational quality in propelling exports and economic growth.

The first quadrant shows the positive relationship between tax revenues as a percentage of GDP, Tax 1, and spending on education, Gasto1. Quadrant (1) shows the positive relationship between spending on education and its quality, Calid1, according to Figure 1. Quadrant (3) shows the positive relationship between the quality of 
education and exports per capita, Exp 1. The estimated equation is:

Exportspercapita $=-12486.71+4131.00$ CualiExports +20.3241 Third grade reading

R squared $=0.67$

Where CuailExports indicates the case of Chile.

With this base, the positive relationship between the tax rate, Tax 1, and exports, Exp 1 is constructed in quadrant (4).

Quadrant (5) shows the association between quality of education, Calid1, and the corresponding economic growth rate, Crec1, as has been shown for Latin American countries by Hanushek and Woessmann (2009) and Cáceres (2018). Based on the relationships shown in quadrants (4) and (5), the positive relationship between the tax rate, Tax1, and the economic growth rate is constructed in quadrant (6), which depicts a relationship where an initial tax increase has led to increased economic growth Crec1.

Quadrant (7) shows the increase in tax revenue, Tax2, which results from the increase in the economic growth rate. In other words, the economic dynamism generated by improvement of quality of education gives rise to a higher tax revenue, which in turn leads to increases in spending on education, Gasto 2, as shown in quadrant (8). With this quadrant and quadrant (6) the positive relationship between the original tax revenues, Tax 1, and the subsequent increase in education spending, Gasto 2, is constructed in quadrant (9). This indicates that the original additional fiscal effort subsequently led to increases in education spending and in its quality.

In quadrant (10) it is shown that the increase in spending on education Gasto 2, gives rise to another round of improvements in quality of education, Calid 2, which in turn leads to increasing exports, Exp 2, shown in quadrant (11). Based on this and quadrant (9), the positive relationship between the original tax rate and subsequent exports is described in quadrant (12), while quadrant (13) describes the relationship between the original quality of education and future exports. Quadrant 14 shows the relationship between Calid 2 and Crec 2 . Of particular interest is the association shown in quadrant 15 between the original tax effort, Tax 1 , and the future economic growth, Crec 2.

The relationships of special interest in this Figure are, firstly, the associations between the original quality of education and future exports (quadrant 13), as well as the association between future exports and the original tax rate (quadrant 12), and the relationships between the original tax rate and future economic growth (quadrant 15), and between future quality of education and future economic growth (quadrant 14).

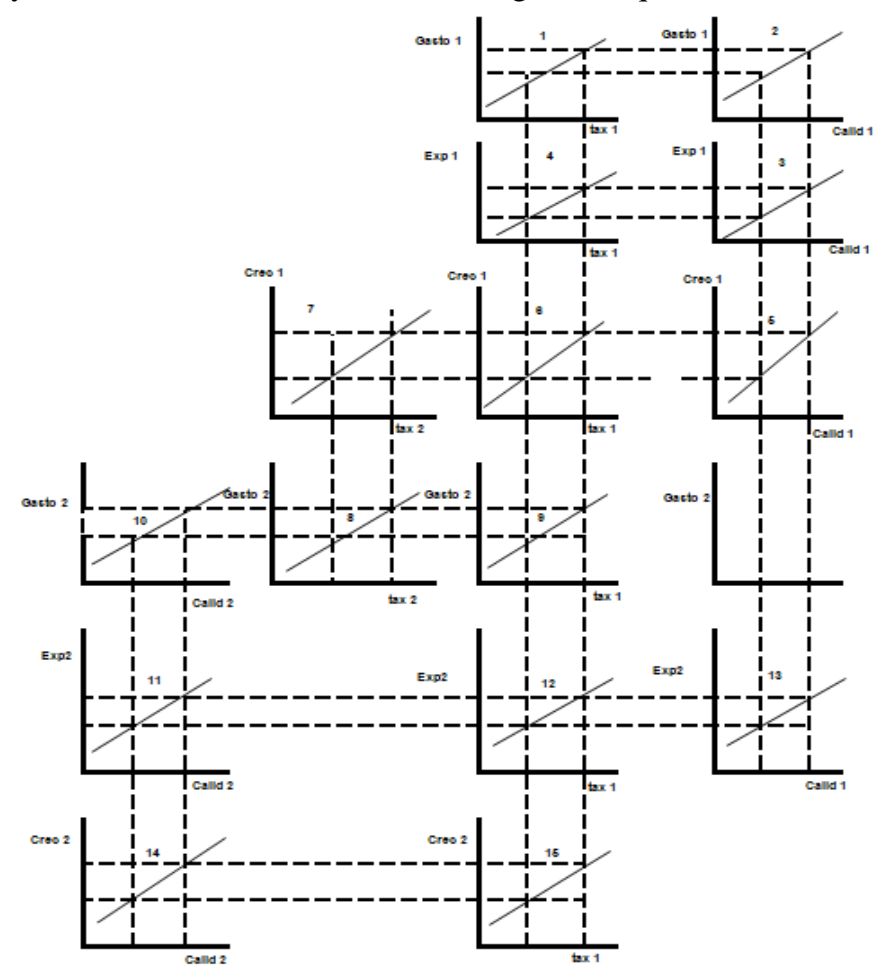

Figure 8. Virtuous circles from education quality 


\subsection{History and Quality of Education}

Just as it is possible that a strong initial impulse to education expenditures and to the quality of education gives rise to the development of a virtuous circle, as shown on Figure 8, the absence of that impulse can lead to a vicious cycle of stagnation of quality of education and exports and economic growth.

A current low level of quality of education can be seen as a reflection of poor support for education in the past, which can be related to the weak mobilization of tax resources; that is to say, low taxation in the past did not allow governments to carry out investments of great magnitude in education and health that would have led to the future development of exports and innovations. This can be associated with the low priority that the development of human capital has received throughout history in Latin American countries, and with the reluctance by high-income groups to pay taxes.

Sokoloff and Zolt (2004) have presented per capita tax revenue data in the year 1870, in US dollars, for 10 Latin American countries and, as shown in the following Figures, this 1870 fiscal indicator is a "very early" indicator of quality of education in 2013, and of other macroeconomic variables of Latin American countries today. Figure 9 shows the positive relationship between per capita taxes prevailing in 1870, Tax 1870, and the third-grade reading scores in 2013, Tercerolectura. This Figure implies that current low quality of education in the region can be seen as an "inheritance" of past low tax revenues in the past.

It can be argued that current quality of education reflects the level of taxation of about 150 years ago. In other words, deficient quality of education has been reproduced over time, reflecting the low initial taxation efforts. In countries with high initial per capita tax revenues, it was possible to carry out investments in human capital that generated increases in economic growth and thus created additional tax revenues, which in turn allowed the continuation of high investments in human capital. The opposite case occurred in countries with low initial levels of taxation.

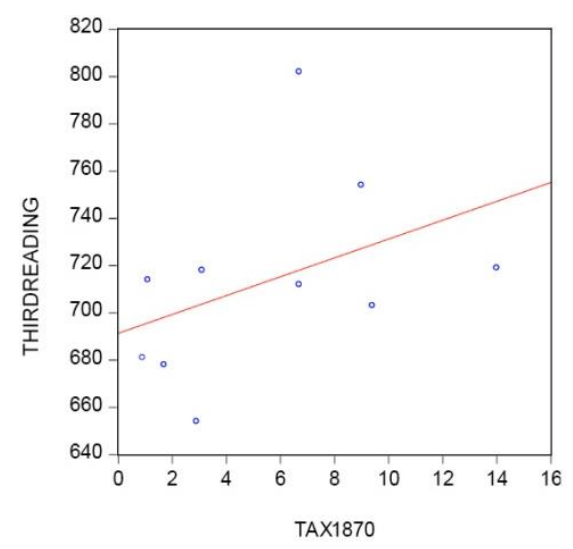

Figure 9. Taxes Per capita in 1870 and third grade reading scores in 2013

The positive association between Tax 1870 and the rates of private investment in 2013, private Investment, (Figure 10), and of economic growth, economic growth, (Figure 11), should be highlighted.

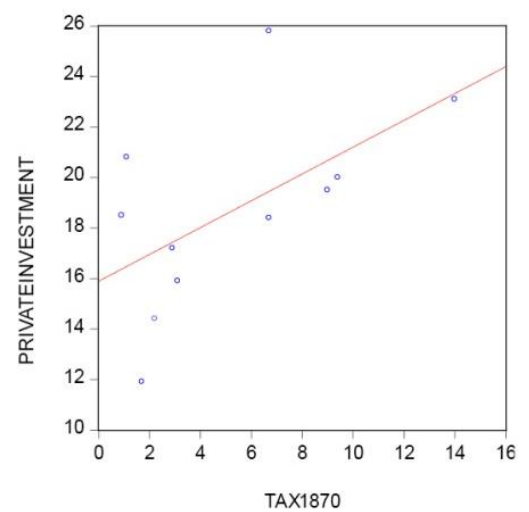

Figure 10. Tax per capita revenues in 1870 and private investment rate in 2013

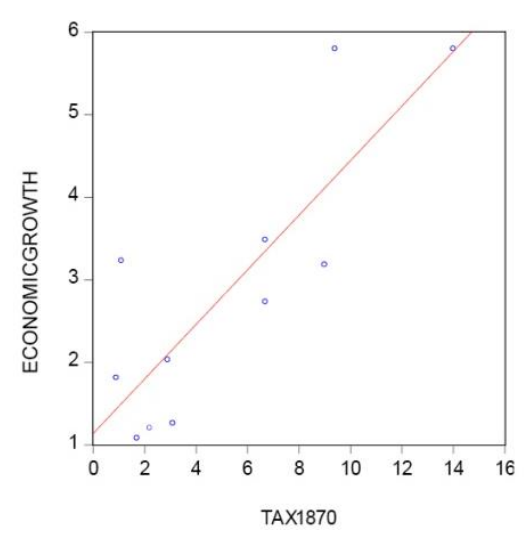

Figure 11. 1870 tax per capita revenues and annual per capita rate of economic growth (2005-2012) 
Table 8 below presents the results of the estimation of equations that express the role of per capita taxes in 1870 on quality of education, and spending on education, and economic growth in 2013.

Equations 1 and 2, whose dependent variables are the third-grade results in the reading and mathematics tests respectively, show that the coefficients of the variable Tax 1870 are significant, together with the qualitative variable 'Cuali', which takes the value of unity when the dependent variable corresponds to Chile.

The R2 of these equations are around 60 percent, indicating that the tax effort of a century and a half ago explains more than half of the variance in the quality of education in a sample of Latin American countries in 2013. Equation 3 shows that Tax 1870, together with the qualitative variable, explains about half of the variance of public spending on education as a percentage of GDP in 2013. One implication is that if the tax effort is not increased, the situation of low-quality education will continue to reflect the past, and economic and social development will continue being elusive.

It can be argued that an initial increase in tax resources will generate subsequent increases in tax revenues due to the increase in economic growth resulting from the original additional expenditure in the quality of education. In other words, it is possible to create a virtuous circle on the supply side of the economy by increasing tax revenues. On the contrary, the fall in taxation can lead to persistent subsequent declines in economic growth and tax revenues, to the extent that productivity and economic growth contract in the face of the deterioration of human capital.

Thus, the only curve that matters is the one showing in Figure 8 that increasing current tax revenues leads to additional education expenditures, (quadrant 9), to subsequent improvements in the quality of education, (quadrant 10), and increasing economic growth (quadrant 15). The rest is fake news (Note 1).

Of special interest is the result of equation 4 on table 8 , whose dependent variable is the average per capita annual growth rate in the period 2005-2012. The coefficient for Tax 1870 is significant and explains 67 percent of the variance of economic growth even without a qualitative variable.

It's valid to deduce that the economic growth of the present partly reflects the low tax revenues of the past, or rather the lack of political will to mobilize tax resources and allocate them to education, 150 years ago. It can be postulated that the decision to increase taxation in some countries led to the initiation of cumulative process of human capital generation, which is reflected in the relatively high levels of human development today.

Table 8. 1870 taxes per capita, in US dollars, and quality of education in 2013

\begin{tabular}{|c|c|c|c|c|}
\hline \multirow[t]{3}{*}{ Dependent variables: } & $\begin{array}{r}\text { Scores on: } \\
\text { Third grade } \mathrm{R}\end{array}$ & e Mathematics & $\begin{array}{l}\text { Expenditure on } \\
\text { Education (\%GDP) }\end{array}$ & \multirow[t]{2}{*}{ Economic Growth } \\
\hline & \multicolumn{3}{|c|}{ Equation number: } & \\
\hline & $(1)$ & $(2)$ & (3) & (4) \\
\hline \multirow[t]{2}{*}{ Constant } & 683.8126 & 681.6470 & 3.3874 & 0.9444 \\
\hline & $(44.37)$ & $(47.58)$ & $(8.05)$ & $(2.60)$ \\
\hline \multirow[t]{2}{*}{$\operatorname{Tax} 1870$} & 3.7650 & 4.4263 & 0.2926 & 0.3351 \\
\hline & $(1.60)$ & $(2.03)$ & $(3.46)$ & $(5.80)$ \\
\hline \multirow[t]{2}{*}{ Cuali } & 101.5821 & 81.2694 & -2.8163 & \\
\hline & $(1.87)$ & $(2.76)$ & $(2.61)$ & \\
\hline $\mathrm{R} 2$ & 0.69 & 0.58 & 0.47 & 0.67 \\
\hline
\end{tabular}

\subsection{Quality of Education, National Savings, Investment, and Economic Growth}

Given that the quality of education is a determinant of private investment, it's possible that the lack of quality education in a country becomes an obstacle to the dynamism of investment and economic growth. If this occurs in countries that are members of an integration scheme, their intraregional trade flows and the external sectors in general could become stagnant. The relationship between the quality of education and investment is analyzed next, in a framework in which the economy in question requires a minimum of skills or knowledge to give rise to the growth of investment.

In Figure 12 national saving is given initially by the function $\mathrm{S}(1)$, which reflects the level of knowledge H1. Savings, (Ahorro), grows along the horizontal axis, thus sustaining the investment shown on the vertical axis.

Investment, for its part, generates the economic growth rate shown on the left horizontal axis. Upon reaching point S1, national savings no longer translate into investment, due to the limitations or lack of knowledge and 
skills required by investment. At this point increasing investment requires additional knowledge of operations management and co-ordination, as well as additional innovations.

If this knowledge gap were not resolved, investment would not increase to levels above I1, and thus the economy would enter a period of stagnation at a persistent growth rate of $\mathrm{g} 1$.

The knowledge gap can be bridged through increases in the quality of education, through increases in spending on education, (see Figure 1), so that the acquisition of new skills by the population would lead to national savings being now given by the function $S(2)$. It is observed that $S(2)$ has a greater slope than that of $S(1)$ because the increase in the quality of education has led to an increase in the rule of law (Cáceres, 2018a), which contributes to increasing investment.

National saving grows to point S2, giving rise to I2 and g2; after which skills become again insufficient or obsolete to transform saving into investment. This situation of economic stagnation can be overcome by the generation of human capital with higher levels of education quality and with the generation of innovations, which will sustain growth rates above g2.

It should be noted that when there is a knowledge gap, an ex-ante overabundance of national savings may occur which, in the absence of adequate knowledge to turn savings into investment, dissipates into private overconsumption and consequently, the national savings rate falls. This shows that behind the savings gap, and behind the external gap, typified by the two-gap model, one can find a gap that determines both, which is the knowledge gap.

Another implication is that in an integration scheme, intra-regional trade may eventually lose dynamism and momentum, because of the population's weak skills and knowledge, and the low capacity for innovation. This shows that within the framework of an integration scheme, development of human capital and the generation of innovations have important relevance to impart dynamism to intra-regional trade flows. In other words, it can be argued that development of quality human capital is an essential element to impart dynamism to economic integration.

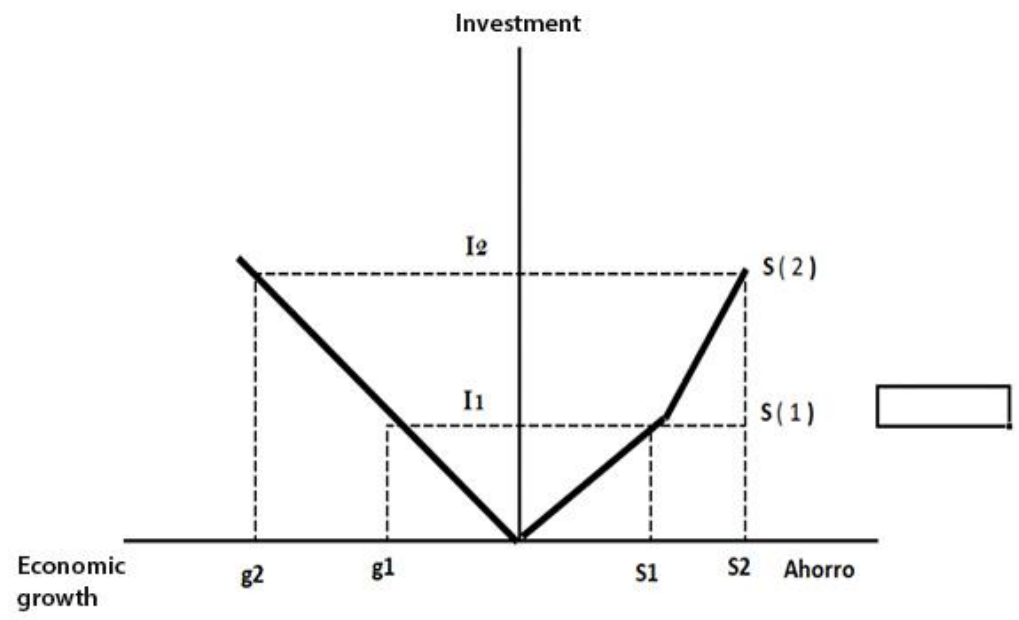

Figure 12. Knowledge gap as a constraint to economic growth

\subsection{Regional Quality of Education Strategy}

It's convenient to structure a strategy for the quality of education at the Central American level that would allow each country to advance in this field, taking advantage of the benefits that exist because of concerted regional actions.

This strategy would include the design and execution of national actions according to an agreed schedule and, likewise, would include actions of a regional nature based on consensus about areas where concerted actions can beneficial.

Within the scope of national actions, those aimed at reducing the number of students per teacher, by building added school infrastructure and hiring more teachers, stand out. At the regional level, an action of special importance would be executing joint actions geared towards obtaining international co-operation resources to allocate them to areas that promote the quality of education. Other areas of special regional importance are the 
preparation of content in specific subjects, such as mathematics, sciences, and the teaching of indigenous languages, as well as the production of textbooks.

In special importance would be adoption of regional policies that will have the consensus of the Central American countries, in terms of supporting single mothers, supporting children with special education needs, those with disabilities, and LBGT students, as well as the indigenous and Afro-Central American student populations, among others. Figure 13 presents a summary of national and regional actions related to quality of education.

One element of the regional strategy would be the adoption by the Central American countries of a common framework for evaluation and monitoring and the measurement of results, with the understanding that said evaluations would be presented to the Central American Presidents at their periodic meetings. Among the variables that would be subject to monitoring and evaluation, would be the following: public sector expenditure on education, number of students and teacher, scores on national and international standardized tests, female and male dropout rates, adolescent fertility rate, percentage of children who don't work or study, coverage of special education and early childhood development, enrollment in technical education, number of computers per pupil, teacher salaries, percentage of teachers with pedagogical training, number of reported cases of violence at school, among others.

\begin{tabular}{|c|c|}
\hline National actions & Regional actions \\
\hline Increase public sector expenditure in education & Joint actions to obtain financial resources \\
\hline Investment in school infrastructure & Production of teaching content \\
\hline Investment in technology & Regional gender policy \\
\hline Decrease number of students per teacher & $\begin{array}{l}\text { Regional education policy directed to Indigenous and Afro } \\
\text { Central American populations }\end{array}$ \\
\hline Teacher accountability system & Regional special education policy \\
\hline Number of books & Regional policy to attend needs of persons with disabilities \\
\hline Teaching in Native languages & $\begin{array}{c}\text { Preparation of content on Indigenous and Afro Central } \\
\text { American cultures }\end{array}$ \\
\hline Building libraries & Regional literacy policy \\
\hline Reduction of school desertion & Regional policy of measurement results \\
\hline
\end{tabular}

Figure 13. National and regional actions to support the quality of education

\section{Conclusions}

This paper has presented evidence that the quality of education has regional impacts on the economic growth of member countries of an integration scheme.

It should emphasized that the increase in the third grade reading score by 50 points in Guatemala and El Salvador allows these countries to increase their economic growth rates respectively by 1.1 and 0.8 percent; in the scenario in which the other Central American countries also increased their public spending to obtain similar increases in their scores in this test, the impacts on the growth rates of Guatemala and El Salvador would result in additional increases of 0.12 and 0.2 percent respectively. This scenario is based, of course, on the premise that Central American countries undertake coordination efforts in matters of economic and education policies.

In view of the additional increase in economic growth that El Salvador receives, over a 25 -year horizon, the accumulated additional GDP would be 25 percent, which would lead to an additional tax collection of 4.5 percent, higher than the 3.3 percent required to increase the score in 50 points. In other words, concerted regional action to increase the quality of education "reduces" the costs of the required investments. This can be called a creation of regional externalities of a social nature, which has been unnoticed in the literature on economic integration.

It is apparent that the additional economic growth resulting from regional coordination are "free" for the Central American countries, given that their efforts at the national level become "more productive", since the other countries are carrying out similar efforts, which energize their own economies, as well as intra-regional trade and the economies of other countries in the region. This is a case in which regional concerted actions give rise to social externalities of economic growth through consensual actions for increasing the quality of education.

Given the evidence that the quality of education is an important determinant of private investment, it follows that 
the "business climate" passes through the quality of education. The case could happen that despite various measures to improve the business climate, private investment doesn't react positively due to poor and stagnant quality of education. Another implication is that the pressures and arguments to reduce taxes are contradictory with respect to the objective of increasing private investment and economic growth, and, in general terms, with the purpose of improving the wellbeing of the population.

In recent years much attention has been given to the issue of "trade facilitation", and many countries have made significant investments in this field. It should be noted that according to the results of this study, the quality of education, as well as public spending on education, constitutes a valuable trade facilitation measure.

It should be noted that the benefits in terms of economic growth derived from the customs union between Guatemala and Honduras, which was initiated in 2018, have been estimated at 1.1 and 0.8 percent per year (Redondo, 2018), magnitude of the same order of size as what these countries would achieve through increasing their third-grade reading scores by 50 points.

When Central American countries undertake simultaneous and concerted improvements in the quality of education, the resulting increases in economic growth in the countries will be of greater dimension than in the case when the improvement in education quality occurs in only one country. It follows that there are regional external economies that act to make investments in national education more "efficient". This has implications for the profitability of human capital investments, as well as for providing the economies of the integration scheme with greater resilience to the ups and downs of the international economy. Hence the importance of reaching regional agreements to promote the quality of education and in general terms to promote human development.

It can be deduced from the results present in this paper that the economic integration process can reach a point of "saturation", or stagnation, that would manifest itself in the stagnation of intra-regional trade. This can overcome by boosting the quality of education and hence the capacity for innovation. One implication is the importance that the region under economic integration be an area of continuous generation of knowledge and innovation.

The important benefits resulting from implementing an import substitution model like the one that prevailed until the early 1990's should be highlighted. These benefits are additional to the increases in economic growth, since the increase in intra-regional trade would serve as a springboard to increase extra-regional exports, according to the evidence presented by Smith and Venables (1988) that economic integration in the EEC countries led them to increases their extra-regional exports, in view of the reduction in costs due to the economies of scale that the expanded market offered. Likewise, Webb and Fackler (1993) have shown that Costa Rica's extra-regional exports were preceded by the export of the same products to the Central American market.

In fact, there is a case to analyze the costs and benefits of integration in broader and dynamic terms that include aspects of knowledge generation, promotion of extra-regional exports, and regional coordination, among others, which would be more relevant than the method of computing measures of trade creation and diversion, which falls short of understanding the diversity and complexity of the integration process.

It should be emphasized that the increase in the quality of education, as well as in import substitution, in as much as they stimulate intra-Central American trade, would increase quality employment, according to the evidence presented by Cáceres (2018b) for the case of El Salvador, which would also contribute to reducing violence. This is another issue that should be included in the analysis of the costs and benefits of integration, especially considering that in some Central American countries the growth of the world economy, represented by the US economy, does not contribute to increasing quality employment (Cáceres, 2021).

The quality of education has other benefits in addition to boosting economic growth: it boosts governance, reduces self-employment and violence, and stops irregular emigration (Cáceres, 2018b). For this reason, efforts to invest in higher levels of human capital in Central American countries must have the support of the international cooperation, given that donor countries obtain benefits from this type of investment.

In this sense, Central American countries with the support from the international agencies of international co-operation, should reach agreements to reach specific goals related to human capital in a certain period, comprising prenatal care, coverage of early childhood education and technical education, pedagogical preparation of teachers, school infrastructure, and public health, as well as emergency employment programs, in a scheme of shared costs and benefits.

It must be emphasized that in Latin America the main motivation or argument for the creation of regional integration schemes has rested on their role in boosting industrialization and economic growth, because of the economies of scale that result from the expanded market (Prebisch, 1950). The results shown in this paper highlight that this argument maintains its validity in the framework of the external economies resulting from 
regional agreements on social development.

In addition, an integration scheme with increasing quality of education, and with continuous generation of innovations, may prevent the integration process from losing dynamism, particularly if regional consultation is used as an integration instrument. The increasing amount of human capital would contribute to strengthening the institutions, in view of the evidence that in Latin American countries both the indicators of accountability and control of corruption, as well as the rule of law, increase as a country acquires higher levels of human capital (Cáceres, 2010).

These results also demonstrate the feasibility of achieving regional endogenous growth and, furthermore, offer an analytical framework to the theories related to economic growth in a regional context.

There is much to be gained by designing policies that are consistent with the experiences of now-developed countries, which show that social development precedes economic development (Easterlin, 1981), which demands the adoption of human capital development as the priority of the public sector.

\section{References}

Arias, O., Yamada, G., \& Tejerina, L. (2002). Educación, Antecedentes Familiares y Desigualdad Interracial del Salario en Brasil. Working paper, IADB.

Barro, R. J., \& Jong-Wha, L. (2001). International Data on Educational Attainment: Updates and Implications. Oxford Economic Papers, 53, 363-394. https://doi.org/10.1093/oep/53.3.541

Cáceres, L. R. (2010). Human Development, Governance and Unemployment in Latin America. Revista Interamericana de Derechos Humanos, 51.

Cáceres, L. R. (2018a). Hechos Estilizados sobre la Calidad de la Educación en América Latina. Unpublished.

Caceres, L. R. (2018b). Des-industrialización, Trabajo y Violencia en El Salvador. Revista de la Cepal. https://doi.org/10.18356/09a279fd-es

Caceres, L. R. (2021). Labor Markets and Social Externalities in Central America. Journal of Developing Areas. https://doi.org/10.1353/jda.2021.0097

Card, D., \& Kreuger, A. (1992). Does School Quality Matter? Returns to Education and the Characteristics of Public Schools in the United States. Journal of Political Economy, 100, 1-40. https://doi.org/10.1086/261805

Daton, P., \& Marcenaro-Gutieerez, O. D. (2010). If you Pay Peanuts do you Get Monkeys? A Cross Country Analysis of Teacher Pay and Pupil Performance. Royal Holloway College, University of London.

Easterlin, R. (1981). Why Isn't the Whole World Developed? The Journal of Economic History, 41. https://doi.org/10.1017/S0022050700042674

Engerman, S. (1968). Regional Apects of Stabilization Policy. In L. Needleman (Ed.), Regional Analysis (pp. 277-326).

Hanushek, E. \& Kimbo, D. (2000). Schooling, Labor Force Quality, and the Growth of Nations. American Economic Review, 90, 1184-1208. https://doi.org/10.1257/aer.90.5.1184

Hanushek, E. (2005). Economic Outcomes and School Quality. International Institute Education Planning, UNESCO.

Hanushek, E. A., \& Woessmann, L. (2007). Education Quality and Economic Growth. The World Bank. https://doi.org/10.1596/1813-9450-4122

Hanushek, E. A., \& Woessmann, L. (2009a). Do Better Schools Lead to More Growth? Cognitive Skills, Economic Outcomes and Causation. NBER working paper 14633. https://doi.org/10.3386/w14633

Hanushek, E. A., \& Woessmann, L. (2009b). Schooling, Cognitive Skills and the Latin American Growth Puzzle. NBER working paper 15066. https://doi.org/10.3386/w15066

Hanushek, E., Piopiunik, M., \& Wiederhold, S. (2014). The Value of Smarter Teachers: International Evidence on Teacher Cognitive Skills and Student Performance. Munich Discussion Paper No. 2014-51, Department of Economics, University of Munich. https://doi.org/10.3386/w20727

Jackson, C. K., Johnson, R. C., \& Persico, P. (2015). The Effects of School Spending on Educational and Economic Outcomes: Evidence from School Finance Reforms. NBER working paper 20847. https://doi.org/10.3386/w20847 
Jamison, E. A., Jamison, D. T., \& Hanushek, E. A. (2007). The Effects of Education Quality on Mortality Decline and Income Growth. Economics of Education Review, 26, 772-789. https://doi.org/10.1016/j.econedurev.2007.07.001

Lee, J. W., \& Barro, R. (2001). Schooling Quality in a Cross-Section of Countries. Economica, 68, 465-488. https://doi.org/10.1111/1468-0335.00257

McEwan, P. J., \& Marshall, J. H. (2004). Why Does Academic Achievement Vary Across Countries? Evidence from Cuba and Mexico. Education Economics, 12, 205-227. https://doi.org/10.1080/0964529042000258572

Meltzer, L. A. (1950). A Multiple Region Theory of Income and Trade. Econometrica. https://doi.org/10.2307/1907833

Prebisch, R. (1950). El Desarrollo Económico de América latina y Algunos de sus Principales Problemas. CEPAL. Santiago.

Redondo, M. (2018). Estado de la Situación de la Integración Económica Centroamericana. Guatemala, SIECA.

Rodrik, D. (1998). Globalization, Social Conflict and Economic Growth. The World Economy, 21(2), 143-158. https://doi.org/10.1111/1467-9701.00124

Schuetz, G., Ursprung, H. W., \& Woessmann, L. (2008). Education Policy and Equality of Opportunity. Kyklos, 61, 279-308. https://doi.org/10.1111/j.1467-6435.2008.00402.x

SERCE. (2008). Segundo Estudio Regional Comparativo y Explicativo de Los Aprendisajes de los Estudiantes de America Latina y el Caribe. Unesco, Santiago de Chile.

Smith, A., \& Venables, A. (1988). Completing the Internal market in the European Community. European Economic Review, 32. https://doi.org/10.1016/0014-2921(88)90113-4

Sokoloff, K., \& Zolt, E. (2004). Inequality and the Evolution of Institutions of Taxation: Evidence from the Economic History of the Americas. In S. Edwards, G. Esquivel, \& G. Marquez (Eds.), The Decline of Latin American Economies: Growth, Institutions, and Crisis. University of Chicago Press.

Tsounta, E., \& Osueke, A. I. (2014). Whats is Behind Latin America's Declining Income Inequality? IMF working paper 14/124. https://doi.org/10.5089/9781498378581.001

UNESCO-TERCE. (2016). Tercer Estudio Regional Comparativo y Explicativo. Unesco, Santiago de Chile. https://doi.org/10.22201/iisue.24486167e.2016.152.57607

Webb, M., \& Feckler, J. (1993). Learning and the Time Interdependence of Costa Rican Exports. Journal of Development Economics, 40. https://doi.org/10.1016/0304-3878(93)90087-4

Woessman, L., \& West, M. (2006). Class Size Effects in School Systems Around the World: Evidence from Between Grade Variations in TIMSS. European Economic Review, 50, 695-736. https://doi.org/10.1016/j.euroecorev.2004.11.005

Woessmann, L. (2003). Schooling Resources, Educational Institutions, and Student Performance: The International Evidence. Oxford Bulletin of Economics and Statistics, 65, 117-170. https://doi.org/10.1111/1468-0084.00045

\section{Note}

Note 1. It is opportune to paraphrase Baran's dictum that paper can have better use than writing economic science fiction.

\section{Copyrights}

Copyright for this article is retained by the author(s), with first publication rights granted to the journal.

This is an open-access article distributed under the terms and conditions of the Creative Commons Attribution license (http://creativecommons.org/licenses/by/4.0/). 